\title{
CAUSES OF DELAYS OF MOTORABLE BRIDGE CONSTRUCTION UNDER POSTAL HIGHWAY PROJECTS, DEPARTMENT OF ROADS
}

\author{
Arjun Suwal ${ }^{1}$, Santosh Kumar Shrestha ${ }^{2}$ \\ ${ }^{1}$ SDE Department of Roads \\ ${ }^{2}$ Lecturer, Department of Civil Engineering, Pulchowk Campus, T.U.
}

\begin{abstract}
Successful completion of project can be linked up with timely completion of the project. This paper highlights on causes of delays in motorable bridge construction of Postal Highway Project under Department of Roads in Nepal. Out of 80 bridges under the project, 36are completed and others are under construction. Questionnaires were distributed to 75respondents from employers, consultants and contractors involved in Postal Highway Project. Data were analyzed based on 57 questionnaires received from questionnaire survey; interview with concerned Project Manager, Consultants, Contractors and progress reports. The main causes of delay are unusual low bid by contractors, lack of planned pre-execution of the project, delay in receiving clearances from various government authorities, poor site management and supervision by contractors due to large number of work in hand.
\end{abstract}

Keywords: Delay; Causes; Effects; Remedial measures; Bridges; Postal Highway Project; Department of Roads; Nepal

\section{Background}

Many developing countries have been experiencing cost and time overrun in development projects and sometimes exceed $100 \%$ of the anticipated cost and duration of the project. Schedule overrun is very frequent and is associated with nearly all projects. In Nepal, implementation delays in public sector investments seem to be common features. There are two government agencies formed for road and bridge construction of Nepal. Local Road Network (LRN) constructions have been undertaken by DOLIDAR. Strategic Road Network (SRN) and some of LRN have been undertaken by Department of Road (DOR). There are about 1800 motorable bridges under SRN till FY 2014/15. 773 new bridges are under construction which includes 213 bridges on SRN and 560 bridges on LRN. Almost all the bridge projects are facing schedule overrun and has become great challenge to implementing agency like Department of Road (DOR).

\section{Methodology}

Available data from the department of roads was used to analyze the status of delays on bridges under postal highway projects. From literature review, thirty eight causes of delay were identified and categorized to seven major groups. Five scale importance index of Likert's scale (5 to 1 point scale: strongly agree $=5$, agree $=4$, neutral $=3$, disagree $=2$, strongly disagree $=1$ ) was used to get perception of the participants. Field survey and unstructured interview with concerned Project Managers, Contractors and Consultant was done.

75 Questionnaires were distributed to the engineers of employers, consultants and contractors by using simple random sampling. 57 questionnaires were received and analyzed. Mean. Information were also gathered via unstructured interview with concerned Project Managers, Contractors and Consultant. Data obtained from secondary sources were analyzed using Statistical Package for Social Science (SPSS) quantitatively to find out relationship between various factors involved. 


\section{Data Analysis}

Microsoft Excel and SPSS software was used to analyze data to find frequency distributions, means, standard deviations, reliability and associations between delay and variables causing delay and ranking of causes. Descriptive and inferential statistics was used in data analysis. Statistical test and methods as listed below were done in analysis: a) Mean Score method, b) Reliability Analysis, c) Kendall's coefficient of Concordance, d)Regression Analysis. Bar Charts, Pie charts, Scatter plots and line graph were used to show the interrelations between various parameters.

\section{4. $\quad$ Findings}

Among all 80 bridges undertaken by 5 Project Offices and Divisional Road Office, 62 bridged (78\%) faced schedule overrun. The details of the bridges studied are shown in table below:

\begin{tabular}{|c|l|c|c|c|}
\hline S.N. & \multicolumn{1}{|c|}{ Name of Project offices } & $\begin{array}{c}\text { Total bridges } \\
\text { considered }\end{array}$ & $\begin{array}{c}\text { Schedule } \\
\text { overrun } \\
\text { occurrence }\end{array}$ & $\begin{array}{c}\text { Severity \% of } \\
\text { schedule } \\
\text { overrun }\end{array}$ \\
\hline 1 & Project Office Dhangadi & 12 & 12 & $100 \%$ \\
\hline 2 & Project Office Nepalgunj & 6 & 5 & $83 \%$ \\
\hline 3 & D.R.O., Bhairahawa & 6 & 5 & $83 \%$ \\
\hline 4 & Project Office Birgunj & 25 & 15 & $60 \%$ \\
\hline 5 & Project Office Janakpur & 14 & 14 & $65 \%$ \\
\hline 6 & Project Office Itahari & 80 & 62 & $78 \%$ \\
\hline & Total bridges & & $100 \%$ \\
\hline
\end{tabular}

It revealed that all projects under Project office Dhangadi and Itahari suffered schedule overrun and project office Birganj suffered least with $60 \%$.

\section{Causes of Schedule Overrun}

By analyzing the trimester progress reports, completion reports of various bridge projects, direct interview with Project Managers, consultants and contractors personnel's various causes of schedule overrun are summarized in figure below: 


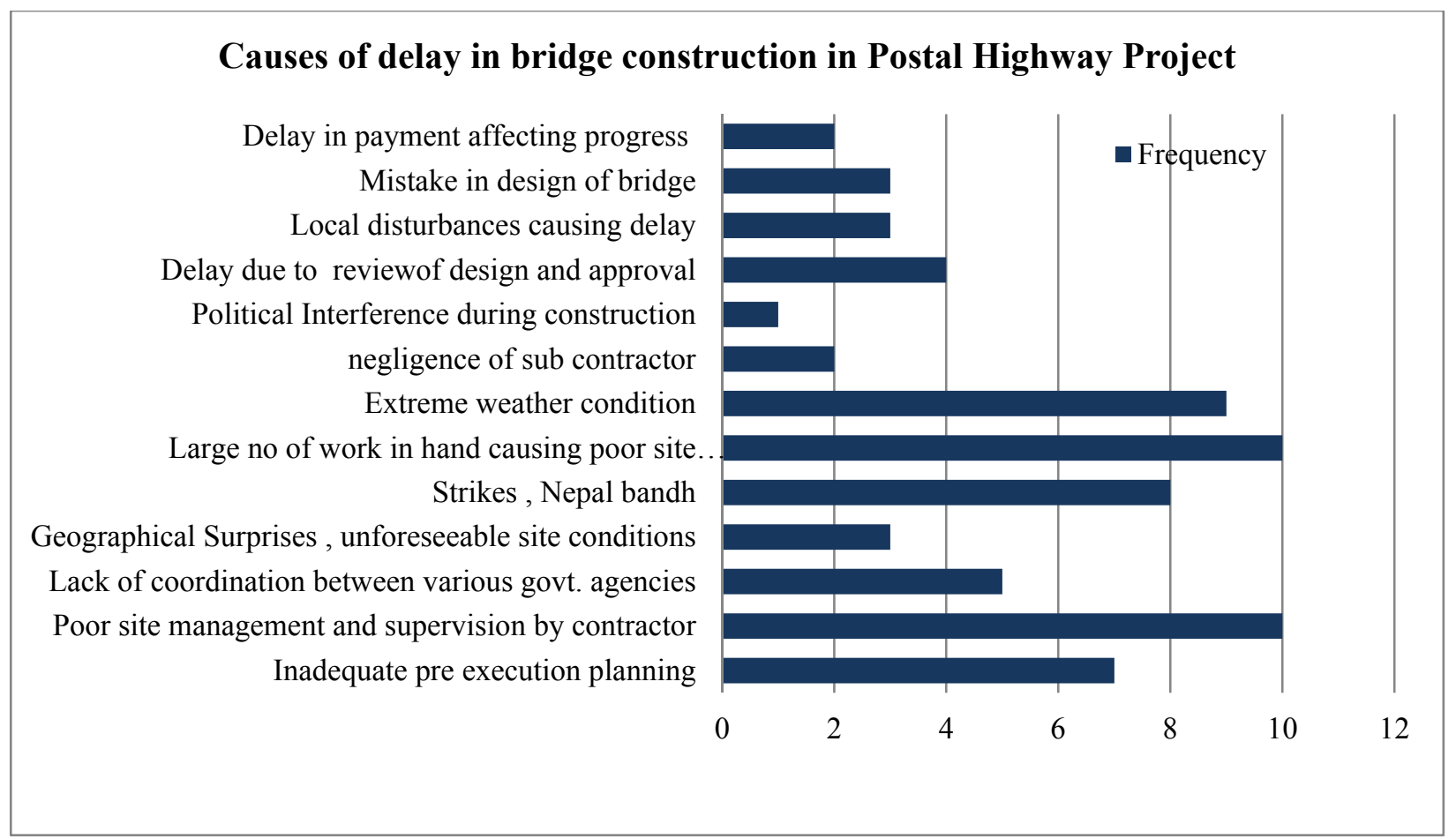

Fig 1 Causes of schedule overrun in Postal Highway Bridge Projects

Figure 1 reveals that poor site management and supervision by contractors, large number of work in hand, external causes such as strikes, Nepal bandh, extreme weather conditions and ineffective pre execution planning and lack of timely decision, lack of coordination between various government agencies seems to be prominent cause of delay in bridge construction project of Postal Highway Project.

\section{Analysis of Questionnaire Survey}

75 no. of questionnaire were distributed. Among them 57 questionnaire (76\%) were received. 23 responses $(88 \%)$ were received from employer, 17 responses $(68 \%)$ from consultant and 17 responses (68\%) from contractor. Based on their responses, causes have been ranked up to 10th position.

\section{Reliability of Research Instrument}

Cronbach's coefficient alpha was used to test the reliability of five point scale used in the survey. The acceptable lower limit for Cronbach's alpha is usually considered to be 0.7 , all the employer, consultant, contractor, labor and equipment, material and external related factors using measurement of internal consistencies approach showed that Cronbach's Alpha are greater than 0.85.These fall within the acceptable value considered for a research instrument's reliability.

\section{Causes of Delay (output from questionnaire survey)}

Collected questionnaire were analyzed and then ranked using mean score method based on importance factor. Views of employer, consultants and contractors were calculated and ranked. Then overall ranking based on mean score obtained was found out. Top ten major causes have been listed out with overall ranking.

Top ten Causes of delay: 1) Unusual Low Bid, 2) Inadequate planning, Pre execution preparation regarding Land acquisition, Utility Relocation, IEE \& EIA approval, 3) Delay in receiving clearance from various authorities (Forest dept., Conservation Park), 4) Poor site management and supervision by contractor due to huge no. of work in hand, 5) Shortage of fuel and power supply, 6) General 
Strikes(Nepal Bandh), wheel locks, riots, 7) Insufficient data collection and survey before design, 8) Shortage of skilled workforce to work in different sites, 9) Ineffective delay penalties, time extension provided for number of times, 10) Poor planning and forecasting regarding construction materials in quarry sites. Kendall's coefficient of concordance was calculated to be 0.352 and 0.193 respectively and which is less than 0.6 and thus the parties involved are considered as independent and no remarkable concordance among employers, consultants and contractors.

\section{Relation between Project Size and Delay}

Contract amount and delay in years were calculated and listed. The figure 2 is obtained by plotting contract amount in $\mathrm{X}$ axis and delay in years in $\mathrm{Y}$ axis. For obtaining the best fit curve, all the possible curves were plotted using SPSS and value of $\mathrm{R}^{2}$ were obtained. The best fit curve with larger $\mathrm{R}^{2}$ value of exponential curve was chosen. From graph it can be predicted that schedule overrun is inversely proportional to the size of the project.

\section{Relation between Work in hand and delay}

Cumulative work in hand of each contractor involved in bridge construction and cumulative delays were calculated and listed. Work in hand and cumulative delay were plotted in $\mathrm{X}$ and $\mathrm{Y}$ axis respectively. For obtaining the best fit curve, all the possible curves were plotted using SPSS and value of $\mathrm{R}^{2}$ were obtained. The best fit curve with larger $R^{2}$ value $=0.469$ was chosen. It was found that small numbers of contractors have occupied huge number of works. Pappu Construction, Kathmandu has occupied about 5 major bridges (cumulative length of $2562 \mathrm{~m}$ ) resulting to 12.16 years of
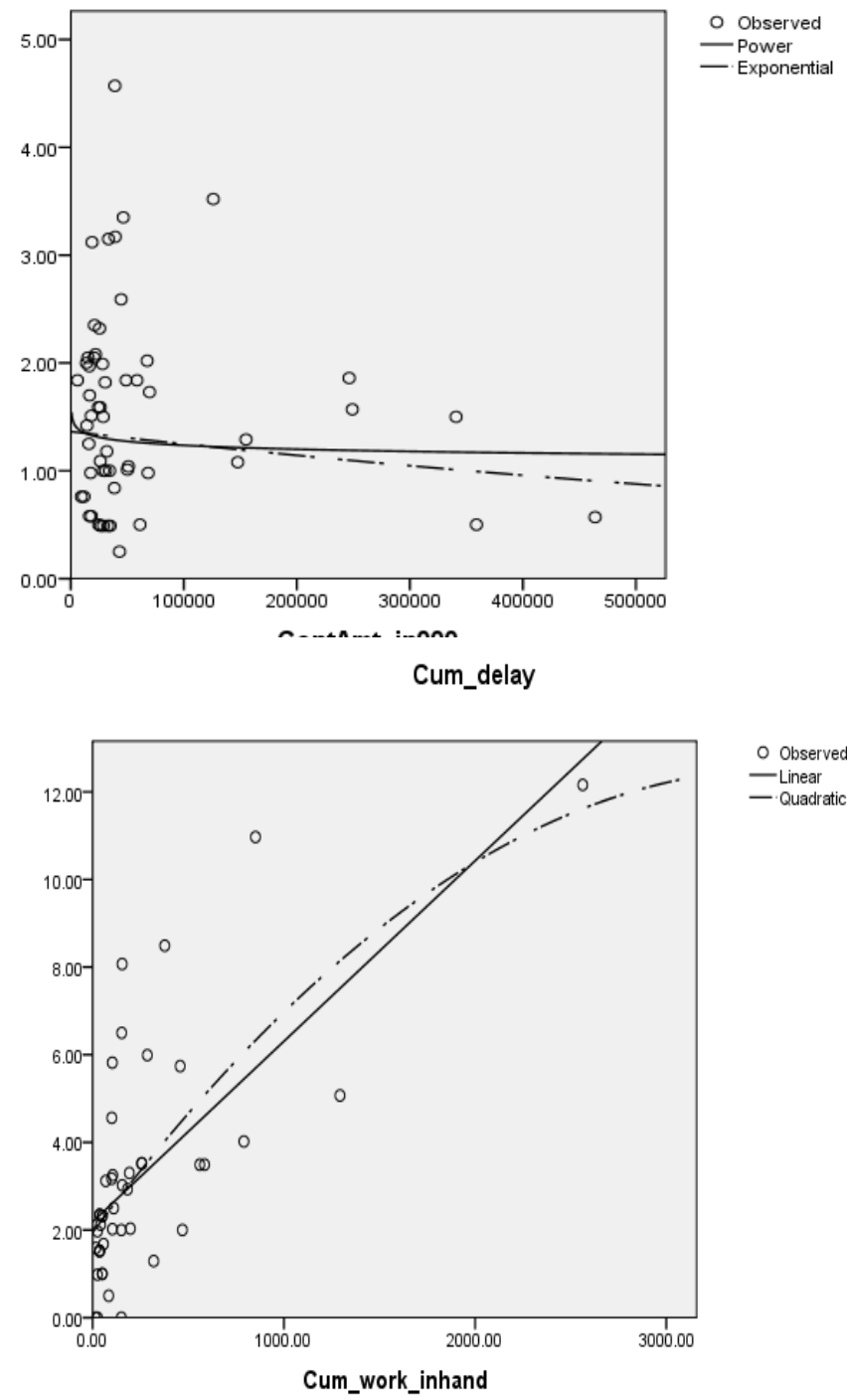
cumulative delay up to date. Lama construction has occupied 6 number of bridges (cumulative length of $851 \mathrm{~m}$ ) resulting to 10.96 years of cumulative delay. Thus, from graph it can be concluded that schedule overrun is directly proportional with work in hand of the contractors.

\section{Relation between trend of change of Project Manager and delay}

Number of change in Project Manager in various project office and average delay per bridge in years was calculated and then plotted in $\mathrm{X}$ and $\mathrm{Y}$ axis respectively. It is found that 9 Project Managers has been changed from date of start of the project (2067) and average delay per bridge is 1.51 years in Project office Dhangadi, while 3 Project Managers has been changed in Divisional Road Office, 
Bhairahawa and average delay per bridge is 0.75 years. From graph, it shows that tendency of change of Project Manager is directly proportional to delays in bridge construction.

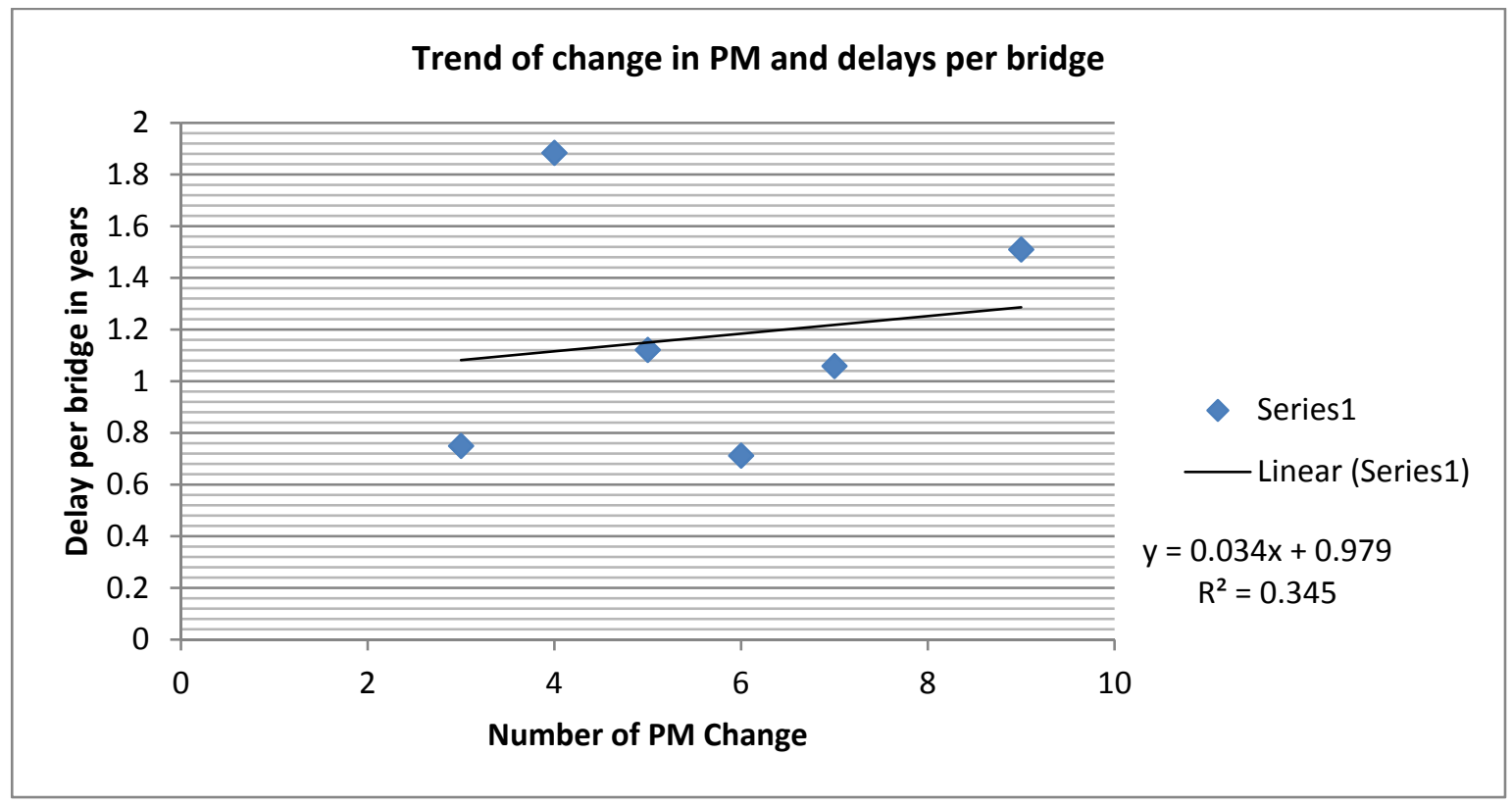

Fig 2 Relation between trend of change of Project Manager and delay

\section{Relation between low bid and delay}

Percentage of lowest bid below engineer's estimate and delays in each bridge was calculated. Graph is obtained by plotting percentage of bid below estimate in $\mathrm{x}$ - axis and schedule overrun in percentage with respect to project period. Best fit curve was obtained by obtaining highest $\mathrm{R}^{2}$ value $=0.76$ for power curve. From graph it can be predicted that more the percentage of bid below estimate amount, higher will be the chance of schedule overrun. There is a tendency to bid unusually, take mobilization and remain silent for long period of time resulting schedule overrun. Among 80 bridges, 9 bridges were found to be quoted with unusual low bid above 30 Percent of engineer's estimated amount. 15 bridges were found to be quoted 20 30 percent of

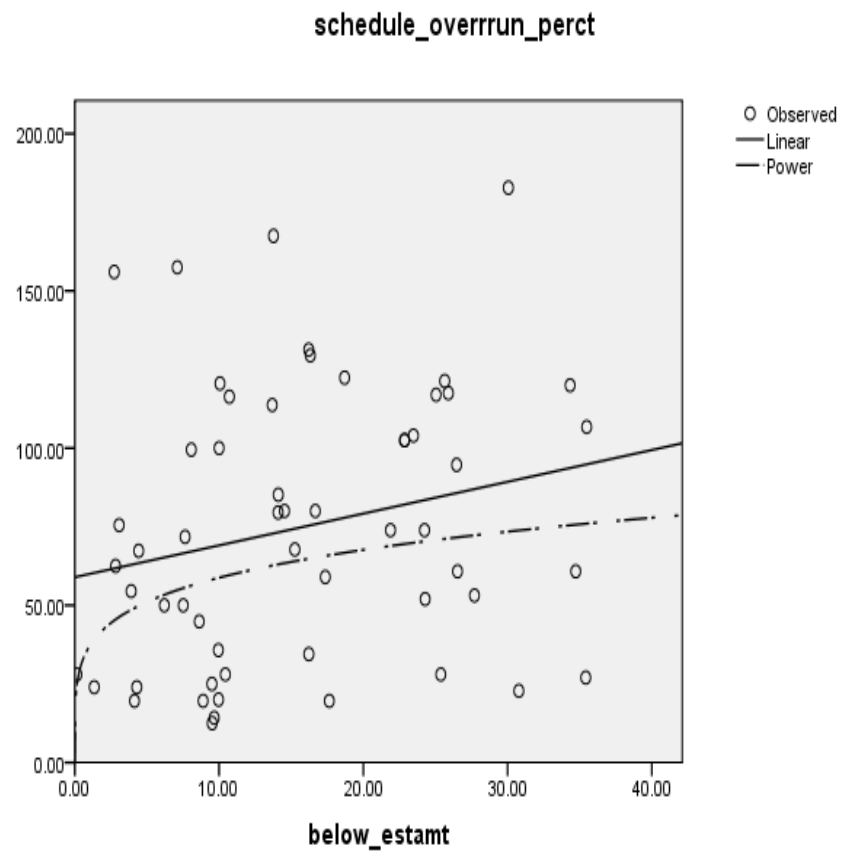
engineer estimate.

\section{Conclusions}

Among 80 bridges studied under this research, 62 bridges faced schedule overrun which is about $78 \%$. Range of schedule overrun was found to be 19 percent to 182 percent. Time period of 16 bridges were found to be extended beyond original project period (greater than 100 percent). Progress of ongoing bridge construction projects is also low and may require longer time to complete the works. 
9 bridges were found to be quoted with unusual low bid above 30 Percent of engineer's estimated amount. 15 bridges were found to be quoted 20 30 percent of engineers estimate. 21 bridges were found to be quoted 10 20 percent of engineers estimate. Based on questionnaire survey, unusual low bid seems to be the first ranking cause of delay and schedule overrun of bridge construction projects.

Inadequate planning, Pre execution preparation regarding Land acquisition, Utility Relocation, IEE \& EIA approval seems to be second major cause of delay. Contract agreement of Narayani, Nala 1,2,3,4 and Thute bridges is done but without EIA and progress of those bridges is zero since 2 years.

Delay in receiving clearance from various authorities (Forest dept., Conservation Park) seems to be third major cause of delay in bridge construction project of Postal Highway Project. Constructions of 6 bridges (Narayani, Nala 1,2,3,4 and Thute) are stopped by Chitwan National Park as those bridges are in buffer zone area and concerned authorities are not ready to grant permission even after EIA.

Poor site management and supervision by contractor due to large number of work in hand is another major cause of delay in Postal Highway Bridge Projects. Small numbers of contractors have occupied huge number of major bridges causing delay and schedule overrun.

Tendency of change of Project Manager of various project offices is also a major problem that caused delay. Within 5 years started from 2067, upto 9 project managers have been changed in Project Office, Dhangadi and 7 project manager in Project office, Birgunj.

\section{Recommendations}

Based on the findings of the research, following recommendations are drawn for minimizing delays in bridge construction projects.

There should be provisions in PPA and PPR to control unusual low bid by increasing performance security as per percentage of bid below estimated amount. ii) Appropriate contractors should be selected based on experience, technical, financial capacity along with consideration of work in hand. The provision of negative marking as per work in hand should be done in Public Procurement Act (PPA) and Public Procurement Rules (PPR), so that tendency of occupying works shall be reduced. iii) Pre-execution preparation (such as land acquisition, utility relocation, EIA and IEE) and planning of project tasks, resource need and appropriate contract strategy to avoid low bid should be done. iv) Strict provisions or limitation on project period variations should be done in PPA and PPR. v) Proper mechanism should be built up for stable and fixed tenure of Project manager in the project.vi) Efficient contract management by employer (quick decision and approval on time). 


\section{References}

1. Abdul El-Razek, M. E., Bassioni, H. A. \&Mobarak, A. M., "Causes of delay in building construction projects in Egypt". Journal of Construction Engineering and Management, 134, 831-841, (2008)

2. Abdul-Rahman, H., Berawi, M. A., Berawi, A. R., Mohammed, O., Othman, M., Yahya, I. A., "Delay Mitigation in the Malaysian Construction Industry",Journal of Construction Engineering and Management. ASCE.Vol 132, No 2, 125-133, (2006)

3. Ahsan, K., and Gunawan, I., "Analysis of cost and schedule performance of international development projects”, International Journal of Project Management, 28(1), 68-78, (2010)

4. Aibinu, A. A. and Jagboro, G.O., "The effects of construction delays on project delivery in Nigerian construction Industry", International Journal of Project Management. Vol.20 (2002). PP 593-599, (2002)

5. Ajibade, A.; Odeyinka, H., "Construction Delays and their Causative Factors in Nigeria", Journal of Construction Engineering and Management. ASCE, 132 (7) 667-677, (2006)

6. Ameh O. J and Osegbo E. E., "Study of relationship between time overrun and productivity on construction sites", International Journal of Construction Supply Chain Management. Vol. 1 (1). PP 56-67, (2011)

7. Assaf S. A. and Al-Hejji S., "Cause of delay in large construction projects", International Journal of Project Management. Vol.24 (4) 2006, PP 349-357, (2006)

8. Creedy, G. D., Skitmore, M., Wong, J. K. W., "Evaluation of Risk Factors Leading to Cost Overrun in Delivery of Highway Construction Projects",. Journal of Construction Engineering and Management.ASCE, Vol. 136 (5) 528-537, (2010)

9. Frimpong, Y., Oluwoye, J., Crawford, L., "Causes of Delay and Cost Overruns in Construction of Groundwater Projects in a Developing Countries, Ghana as a Case Study", International Journal of Project Management, 21, 321-326, (2003)

10. Kothari C. R. and Garg G., "Research Methodology- Methods and Techniques", Third Edition. New Delhi, India: New Age International (P) Limited, (2014)

11. Kuikel S., "Causes of Delay in local road bridge construction of Nepal", Nepal Engineering College, Pokhara University, (2014)

12. Le-Hoai, L., Lee, Y. D., Lee, J. Y. , "Delay and Cost Overruns in Vietnam Large Construction Projects: A Comparison with Other Selected Countries", KSCE Journal of Civil Engineering. Vol 12, Is. 6, 367-377, (2008)

13. Lo, T. Y., Fung, I. W. H., Tung, K. C. F., "Construction Delays in Hong Kong Civil Engineering Projects”, Journal of Construction Engineering and Management, Vol. 132, No. 6, 636-649, (2006)

14. Mansfield, N., Ugwu, O. \& Doran, T., "Causes of delay and cost overruns in Nigerian construction projects”, International Journal of Project Management, 12, 254-260, (1994)

15. Memon, A. H., Rahman, I. A., Akram, M. \& Ali N. M., “ Significant factors causing time overrun in construction projects of Peninsular Malaysia”. Modern Applied Science, 8, 16-28, (2014) 
16. Mohamed, S. F. \&Anumba, C. J., "Potential for improving site management practices through knowledge management", Construction Innovation: Information, Process, Management, 6, 232-249, (2006)

17. Merewitz, L., "Cost Overruns in Public Works", Reprinted from Befinet Cost and Policy Analysis 1972. Ed. William Niskanen et al, Aldine Publishers, Chicago, (1973)

18. Monthly and Trimester Progress Report and completion reports from respective project offices.

19. Okpala, D. C.; Aniekwu, A. N., "Causes of High Costs of Construction in Nigeria”, Journal of Construction Engineering and Management. ASCE, 114 (2) 233-244, (1988)

20. OwolabiJames, "Causes and Effect of Delay on Project Construction Delivery Time". Public Procurement Act 2007 and Public Procurement Rules 2008, Kathmandu: Nepal Law Commission, International Journal of Education and Research, Vol. 2 (2014)

21. PPMO, "Standard Bid Document for Procurement of Works for above 6 Million Rupees" (NCB), (2010)

22. SAMBASIVAN, M. \& SOON, Y. W., "Causes and effects of delays in Malaysian construction industry”, International Journal of Project Management, 25, 517-526, (2007) 